\title{
Elite Conflict Orientations in Polish and US Cities
}

\author{
Samuel J. Eldersveld and Renata Siemienska
}

\begin{abstract}
This paper analyzes the values of local leaders in Poland and the United States. A matched subset of cities is used. Interview data were collected in the 1983-84 period. The focus is on elite views about political conflict. Striking differences were found in the types of problems seen as serious in their communities. Yet, similar proportions perceived and tolerated conflicts today as in 1966. Individual level data on leadership position, party affiliation or status, length of tenure and age revealed differences. And in both countries community differences were considerable.
\end{abstract}

Elite values, particularly the extent of elite value consensus, constitute an important focus in the analysis of any political system. Elite orientations toward social and political conflict constitute a particularly relevant aspect of such analysis. Scholars have from time to time reflected on elite conflict perceptions and beliefs, and there has been some empirical research in this area. What we don't know very much about are the cross-national patterns of elite conflict orientations and the factors which seem to be linked to such orientations. In this paper we explore this problem with data from two "most different" systems, Poland and the United States. The data we use are based on interviews completed between 1982 and 1984 with local political and governmental leaders in five Polish cities and seven US cities of similar size. The exploratory analysis of the data presented here we hope will help us better understand community political systems, and their political leadership, in these two nations.

More specifically, our aims are to:

1. Describe local leaders' awareness of conflicts in Poland and the United States, their evaluations of the impact of such conflicts (whether harmful or salutary), and their personal predispositions (or value preferences) about conflict. These, in a sense, are our three "dependent" phenomena.

2. Analyze the factors underlying, and presumably linked to, these elite orientations, relying on individual variables and exploring also the possible relevance of 
community differences. Our explicit interest here is to see whether such variables help explain cross-national elite views on conflict.

3. Assess the meaning of these findings in the light of conflict theory generally, and in the context of the earlier crossnational findings reported in the "International Study of Values in Politics" (Jacob et al., 1971).

There are, of course, several assumptions underlying this earlier research, as well as the analysis presented here. We assume that the cognitions, perceptions, and evaluations of elites regarding social and political conflict are important orientations, and that if we can discover and understand them (we assume we can study them!) they will provide us with better knowledge about elite behavior and the nature of political life in the communities we study. They are presumably not transient, nor situational orientations but part of, clues to, a basic view of politics. Presumably also they influence leadership attitudes and performance, helping explain the variance which occurs in the attitudes and behavior of such leadership. Finally, we assume that cultural and systemic differences influence the pattern of elite conflict perceptions and evaluations that emerge when we do comparative analysis.

The history of scholarly discussion of social and political conflict is rich, and many great minds have addressed themselves to the "big questions" posed here. Robert Angell argued that for sociologists the beginning was Georg Simmel, particularly his piece on "The Sociology of Conflict" (1904). Some American political scientists would probably take us back to The Federalist in which Madison discussed the inevitability of "factions," at the time of the adoption of the US Constitution. Putnam thinks we should go back to the disagreement between Plato and Aristotle over the essence of social relations (Putnam, 1973: 93-4); others would start with the contrasting views of Hobbes and Marx. Elite theorists might well call our attention to the works of Mosca and Pareto, who recognized the conflict of interests in society, at least implicitly, while arguing for the eventual resolution of conflict leading to a new "balance of social forces" or a societal "equilibrium." In the post-war years quite a few studies dealing with the subject of conflict appeared (see among others UNESCO, 1957; Coleman, 1957; Coser, 1956; Dahrendorf, 1959, 1969; Lipset, 1960; McNeil, 1965; Gamson, 1968; Janowitz, 1970).

In the last decade there seems to have been less attention paid to the study of conflict internal to society than in the preceding decade and a half. More attention has been given recently to arms control, deterrence, and international conflict theory.

Our limited exposure to this body of literature leads us to suggest, rather hesitatingly, that many of the key issues raised by these scholars are still with us. Most people will agree with Dahrendorf's initial position, "Wherever there is human life, there is conflict ...,", but not everyone will agree with his second position, "by conflict alone the multitude and incompatibility of human interests and desires find adequate expression in a world of notorious uncertainty" (Dahrendorf, 1969: 13840). That is, the first issue concerns how we should view the role of conflict in society-inevitable and positive, or unnecessary and negative, at best only to be tolerated. Angell reminds us that great scholars like Parsons in The Social System made conflict "appear as deviant or abnormal" (McNeil: 104). And Harold Lasswell is considered by some to have had less than a positive view of conflict, arguing at one point that "the problem of politics is less to solve conflicts than to prevent them ..." (Lasswell, 1930: 197). Sperlich (1971: 219) argues that David Truman's only real interest in conflict was in its resolution in order to achieve group cohesion. There 
have emerged therefore, two contrasting views of the place of conflict in societyone emphasizing the negative and dysfunctional aspects of conflict and the other taking a more "balanced" view, seeing at least some positive aspects (Sperlich, 1971: 215). Some scholars feel that we have turned of late more in the direction of the former view. As Robert Dahl put it, there has developed a "stability fetish" among American political scientists, emphasizing the needs of a stable democracy and seeing "conflict and change" as "menacing the foundations of existing democracy itself" (Dahl, 1967: 261).

A related second area of controversy is over the function of conflict. Among those who are not entirely negative there has been, again, considerable disagreement. Some scholars defend conflict as necessary for the achievment of consensus, for maintenance of the system. To Dahrendorf this was quite wrong. In one paper he attacked Coser on this point, arguing that while conflict may lead to the effectiveness of a system, that is not its sole purpose. Its value is that it leads to social change. He asks this critical question: "Is the only sociologically relevant consequence of a strike or even of a revolution that it constitutes a tie between the hostile parties?" The answer for him is a resounding No-conflict is relevant in order to change the system for the better. ("Die Functionen Sozialer Konflikte," 1962, discussed in McNeil, 104). Obviously many other functional arguments can, and have been, advanced to support the role of conflict. It is an area, however, over which there is great disagreement.

A third area of controversy is what our expectations should be concerning elite conflict, or rather, variations in the patterns of conflict among elites. This, too, is both a normative and an analytical question, as were the preceding two questions. Eldersveld has argued elsewhere that there are three major approaches to this question of elite relationships (1981: 3-8). There are those who have emphasized elite cohesion as the reality, writing of $a$ "ruling class" or $a$ "power elite." There are those who have emphasized elite conflict as natural and to be expected, as Weber speaks of the inevitable conflict between politician and bureaucrat. And there are those who emphasize elite convergence of perspectives, cooperation, mutual respect, and rapport, despite differences in views and beliefs-such as the theory of elite "accommodationism."

In the seven-nation study of MP's and bureaucrats, two models are presented: (1) the "governance model," which postulates "a monistic public interest," whose adherents see social and political conflict as "marginal, illusory, and often artificial"; and (2) the "politics model" which "endorses a pluralistic conception of the public interest and affirms the reality and legitimacy of conflict" (Aberbach et al. 1981: 1412). Somewhat akin to this distinction is the one made by Gamson between "potential partisans" and "the authorities," the former who do not have power emphasize the importance of conflict for the articulation of needs and problems, while "the authorities" who are the agents of control take a dim view of conflict (Gamson, 1968: 2). These formulations strongly suggest differences in elite conflict orientations as a result of power position and role, as expressed in and influenced by the political culture. They suggest, also, hypotheses we should test with our data.

There is considerable attention paid to these theoretical concerns in the writings of Polish scholars. They tend to share an opinion that conflicts have hampered social and economic development in postwar Poland. For example, Jan Szczepanski, a leading Polish sociologist, has described the elements determining (and limiting) the changes in the economy and society of Poland, with special reference to the role of 
conflicts, as follows:

The failures in managing the socialized economy, the errors in planning and implementing economic policies, led to conflicts between the management and the workers, which contributed to poor performance and created barriers to economic progress. Even more importantly, they had negative effects upon the behaviour of the people, the functioning of the state institutions and enterprises, and last but not least, upon relations between the administration and the people (Szczepanski, 1984: 179).

In another part of his essay Szczepanski answers the question "What next?" by responding that "the answers vary a good deal." Some stress the internal conflicts ... which prevent the evolution of a common programme and exacerbate the difficulties in mobilizing the society to pursue some common goal or to undertake some work which would give meaning to its life." He adds: "Some historians will argue that this has been so for centuries, and that this is almost the normal state of affairs in Poland" (Szczepanski, 1984: 185).

Perceptions of conflict as a hampering factor also prevail in the "Kubiak Report" (a document prepared in 1983 by the special commission of the Central Committee of the Polish United Workers' Party). This report seeks to explain the causes and content of social conflicts in Poland after World War II. This official document reflects the point of view of the ruling party and its ideological and political approach to social conflicts. An awareness of this approach is especially important in the analysis of local leaders' attitudes toward conflict. We can assume that their attitudes are shaped, or are at least influenced, by the ideology of the party of which they are members and which they represent. (A majority of local leaders, about 80 percent, are members of the PUWP.) This report states: "The rightness of the choice of the socialist road has been . . . confirmed by the lasting and irreversible accomplishments of the nation, regardless of the errors which were committed along this road and the accompanying tensions and social conflicts" (Sprawozdanie Specjalnej Komisji KC PZPR, 1983).

Polish scholars and party leaders thus emphasize the existence of conflicts, resulting from managerial decisions and social tensions. They see these conflicts as dysfunctional, having negative behavioral consequences and impeding development of the system. Such conflicts may be seen as ideologically improper. Such conflicts may also be seen as possibly reflecting historical and cultural tendencies.

What emerges from this review of some of the theoretical positions in the United States and Poland is the expectation that the elites in the United States and Poland will differ in their orientations toward conflict. Yet, implicit in such writing is the expectation also that there may be considerable variance in elite conflict beliefs in both countries. The follow-up question then is what types of leaders are pro-conflict or anti-conflict in each system, in perceptions, evaluations, and personal preferences? Are the bureaucrats more, or less, conflict-tolerant than the politicians? Are those in the older cadres of elites more hostile, or less hostile, to conflict than the new, younger, elites? And how does "party" play a role-in Poland is there a "party line" which members adhere to, while this is not true for non-members? In the United States are elites on the "left" more conflict-tolerant than those on the "right"? These and other questions will engage our attention as we sort out the comparative uniformities and contrasts in our data. 


\section{Earlier Empirical Research}

A brief summary of the results of the earlier empirical work is useful to set the stage for our analysis. First, the extent to which political elites are aware of, or emphasize, conflict varies considerably from one system to the next. In Putnam's early study of British and Italian MP's he notes at the beginning the sizeable difference in this concern about conflict-38 percent of the British MP's de-emphasize it (49 percent see conflict as typical or dominant) while only 10 percent of the Italian MP's deemphasize it ( 75 percent see it as dominant or typical). In our seven-nation study we see the same pattern of system differences. When we coded our national elites on the prominence of conflict of interest in their perceptions of politics and society, we found a wide range. Among MP's the percentage who saw little conflict varied as follows: Germany (11), Italy (17), The Netherlands (22), UK and USA (32), France (53), Sweden (55).

The data for the bureaucrats followed the same basic pattern with the Dutch least sanguine (11 percent) and the French most sanguine (61 percent). These are sizeable system differences and have to be understood in terms of the history and development of these societies in the last 60 years during which these elites have come to adulthood and political leadership positions.

The relevance of role or position by itself is not as great as one might expect, in our seven-nation study of bureaucrats and politicians, in the way these two elites look at politics and society. Politicians are somewhat more likely to see conflict and to say that conflict is typical, but the differences are not great (on the average 49 percent compared to 46 percent). As to whether conflict is healthy and contributes to progress, the differences are greater. For example, in The Netherlands while 52 percent of the MP's see conflict as functional to progress only 32 percent of the senior bureaucrats do. The comparable percentages for British elites are 70 percent and $\mathbf{5 5}$ percent. However, this is not true for all countries (Germany is an exception-both civil servants and MP's are equal in their support of the positive function of conflict, up to 70 percent seeing it as linked to progress).

The importance of party and ideology as explanations of elite conflict orientations has been examined. Putnam found in his early study that "Leftists stress conflict, rightists stress harmony" (Putnam, 1973: 106). Yet his data suggest (as he admits) that the far Right is almost as aware of conflict, sensitive and concerned about it, as the Left. This was only slightly more true in Italy than in Britain. Hence to claim that "politicians of the Right are typically consensualists" (129) is difficult to support with his data. Our seven-nation study is more convincing on this point. Our data reveal the following: the mean percent who see little conflict in society is 14 percent for the Left but 43 percent for the Center/Right. Yet, by country, again, there are great differences, as shown in Table 1 (Eldersveld, 1981: 240). Table 1 suggests that the party variable may not always be useful in explaining variations in conflict perceptions.

Other personal sources for explaining leaders' variations have not been explored as carefully, with the exception of social class origins. Putnam argues that father's occupation as well as respondent's own occupational history correlate well with the conflict perceptions of elites. In Britain the parental social class association with conflict is 0.43 , and respondents own occupation correlates as 0.34 . In Italy, because parental social class data were hard to secure, the correlation was strong only for respondent's first and most recent occupation (0.34). Hence the argument is that the lower the social class of origin the greater the likelihood that a political leader will 
Table 1. Conflict Perceptions of National Politicians, by Party

Percent

Seeing Little or

No conflict
Left $\%$
Center/Right \%

Left Center/Right

\begin{tabular}{lrlll}
\hline Sweden & 20 & 84 & 22 & 22 \\
Netherlands & 5 & 44 & 20 & 23 \\
Italy & 0 & 33 & 23 & 33 \\
Britain & 18 & 47 & 46 & 48 \\
Germany & 8 & 14 & 44 & 43 \\
US & 35 & 33 & 22 & 28 \\
\hline
\end{tabular}

operate with a conflict model of politics. This finding holds up even if party is controlled, which suggests that the political and social conflict orientation is very deeply held, developed early in life, and retained despite subsequent partisan and political ideological influences. Linked to this position is a "generational" interpretation of the way in which political leaders are socialized to the acceptance of a conflict (or non-conflict) model of politics. They presumably "take on" an interpretation of politics by the time they reach adulthood, and the particular historical period of a society during their period of adolescence, whether a period of conflict and discord or of harmony and consensus, presumably influences the crystallization of this conflict view of the world of politics (Putnam, 1973: 146).

A few words are needed to summarize attempts to discuss something about the consequences of elite conflict orientations. Putnam argues that these are basic orientations, and influence the way a leader behaves. He seeks to demonstrate that the leader's conflict model influences his approach to specific issues and their resolution (for example, views as to how to handle the problems of crime or poverty). Further, he sees conflict orientations linked to "ideological style," or how a person thinks and reasons about politics, whether as a generalist or a particularist, inductively or deductively, and so on. Third, he sees these orientations as associated with behavioral roles. The two he uses are the "tribune" and the "trustee" (the former focusing on protest and advocacy, the latter focusing on "the defense of national and collective interests"). The correlations are high $(0.61$ and 0.61 for MP's in Britain and Italy). Finally, Putnam and our seven-nation study both see linkages between conflict orientations and other attitudes. Thus, those elites who see conflict as "healthy" and functional are much more likely to support pluralist politics and particularly the participatory role of citizens in the system.

Finally, the study Values and the Active Community has certain pertinent findings about elite conflict orientations for Poland and the United States which antedate our analysis here. ${ }^{1}$ The findings shown in Table 2 from the earlier study are particularly important to keep in mind.

The ISVIP Study discovered that, in explaining community activeness, intensity of conflict in Poland contributed substantially to the variance explained, an increase of 31 percent. In the United States the variance explained was only 6 percent (Jacob, 1971: 307). The conclusion arrived at was that leaders believe conflict in Poland "is 
Table 2. Conflict Perceptions of Local Leaders

\begin{tabular}{|c|c|c|}
\hline & Poland & U.S. \\
\hline$\%$ of leaders reporting conflicts concerning: & $(\mathrm{N}=891)$ & $(\mathrm{N}=905)$ \\
\hline Social Groups & $37 \%$ & $30 \%$ \\
\hline Political Groups & 17 & 27 \\
\hline No Conflicts & 15 & 9 \\
\hline Extent of perceived Community conflict $(\max$ score $=2.00)$ & 1.02 & 1.42 \\
\hline Conflict Avoidance Mean Score (max. 4.00, min. 1.00$)$ & 2.42 & 2.13 \\
\hline
\end{tabular}

a definite hindrance." "Where there is conflict there is less activeness, where the leaders perceive little conflict and few obstacles . . . the community is active" (303). In the United States the conclusion was quite different: "The leaders in active cities value participation, whereas leaders in the less active cities value economic development and the avoidance of conflict" (303, emphasis supplied). Thus, "it appears that socio-political conflict, although operating in quite different ways in each country, provides one of the more cross-nationally important variables" (309). Such earlier findings set the stage for our analysis of the eighties.

\section{The Data}

For this exploratory analysis we have tried to match as closely as possible the cities we select in Poland and the United States. As is well known, we have returned in 1983-84 to the 30 American cities in which the original "Values Project" was conducted in 1966. In each city, from 15 to 30 local governmental, party, civic, and interest group leaders were interviewed. From that set of cities we selected seven, primarily in the Midwest, which are close in population size to the five Polish cities in which interviews were conducted in 1983-84. The reason for the larger number of US cities was the need for an adequate number of respondents on which to base a comparison with the Polish data.

In Table 3 we present population data on the cities selected for our comparison. According to the 1980 census, the Polish cities range from 24700 to 98900 in 1980 population; the US cities range from 30600 to 109700 . All the Polish cities are located in two provinces, Kalisz and Siedlce. In each province about 250 local leaders were selected, primarily on the basis of their positions: as party secretaries, presidents of chapters of the United People's Party and Democratic Party, presidents and deputy secretaries of towns, managers of groups of villages, managers of the more important departments of towns, commission chairmen of town councils, directors of the largest industrial enterprises, principals of the largest schools. Thus, a diversity of functions and roles is included in the Polish sample. The provinces, and administrative units within them, were selected in order to compare communities with higher and lower levels of economic development and industrialization. " $\mathrm{K}$ " province was less rural - 43 percent urban (compared to 25 percent for "S" province), had better medical care facilities, better mass media facilities (TV and radio sets), and better housing 
Table 3. Population of the Polish and American Cities in our Study

\begin{tabular}{|c|c|c|c|c|}
\hline & $\begin{array}{c}\text { Population } \\
1970\end{array}$ & $\begin{array}{c}\text { Population } \\
1980\end{array}$ & $\begin{array}{l}\% \text { Change } \\
1970-1980\end{array}$ & $\begin{array}{l}\text { Number of } \\
\text { Leader } \\
\text { Interviews }\end{array}$ \\
\hline \multicolumn{5}{|c|}{ US Cities in this Analysis } \\
\hline $\begin{array}{l}\text { South Bend, IN. } \\
\text { Waukegan, IL } \\
\text { Hamilton, OH } \\
\text { Dothan, AL } \\
\text { Middletown, OH } \\
\text { Wyandotte, MI } \\
\text { Highland Park, IL }\end{array}$ & $\begin{array}{r}127,328 \\
65,134 \\
67,865 \\
36,733 \\
48,767 \\
41,061 \\
32,300\end{array}$ & $\begin{array}{r}109,727 \\
67,653 \\
63,189 \\
48,750 \\
43,719 \\
34,006 \\
30,611\end{array}$ & $\begin{array}{l}-12.6 \\
+3.9 \\
-6.9 \\
+32.7 \\
-10.4 \\
-17.2 \\
-5.1\end{array}$ & $\begin{array}{r}16 \\
14 \\
15 \\
19 \\
17 \\
13 \\
14 \\
108\end{array}$ \\
\hline \multicolumn{5}{|l|}{ Polish Cities } \\
\hline $\begin{array}{l}\text { Kalisz } \\
\text { Ostrow } \\
\text { Siedlce } \\
\text { Jarocin } \\
\text { Lukow }\end{array}$ & $\begin{array}{l}81,500 \\
49,700 \\
39,300 \\
18,200 \\
15,700\end{array}$ & $\begin{array}{l}98,900 \\
62,500 \\
54,800 \\
21,200 \\
24,700\end{array}$ & $\begin{array}{l}+17.6 \\
+20.5 \\
+28.3 \\
+14.2 \\
+36.4\end{array}$ & $\begin{array}{l}30 \\
38 \\
33 \\
20 \\
22 \\
143\end{array}$ \\
\hline
\end{tabular}

Sources: U.S. County and City Data Book, 1977, 1983 U.S. Bureau of the Census Poland: Statistical Yearbook, 1984, pp. 41 and 43

conditions. As for type of employment, the two provinces were fairly similar: 42 percent to 44 percent employed in industry, 10 percent to 17 percent in transport and communication, 10 percent to 13 percent in trade.

The American cities did vary in certain important respects. They differed considerably in median family income and in educational level. At one extreme is Highland Park, 80 percent or more of whose adult population was fairly well educated (49 percent college-educated), a city with a high median family income of $\$ 42903$ in 1980 . At the other extreme on education are cities like Wyandotte and Hamilton (less than 10 percent with college educations). As for family income variations, Dothan, Hamilton, and South Bend were lowest in 1980.

The US cities also vary much more than the Polish cities in types of employment in 1980. Four cities had a third or more of their labor force in manufacturing, while Highland Park and Dothan were far below that. On the other hand, Highland Park had over 40 percent of its labor force working in professional, service, or selfemployed positions, compared to 17 percent in Wyandotte. Finally, the proportion of blacks in these cities varied from less than one percent in Wyandotte, (1.7 percent in Highland Park) to 25 percent in Dothan (almost 20 percent in Waukegan and South Bend). 
While important differences exist in these cities, as one would naturally expect, their $\mathrm{F}$ opulation size and economic character suggest enough relative similarity to permit us to attempt a comparison of them in elite perceptions of conflicts and elite beliefs about conflict. The Polish study, although focused primarily on the elites' views of needs and problems, and their satisfaction, did ask questions similar enough to those in the American study to permit a joint analysis. In the discussion here we will focus on elite perceptions and attitudes in individual cities in each country and then aggregate the responses for all elites by country. We will use individual variables, in an attempt to explain variance in elite orientations. But we will also describe carefully community differences to see whether elite orientations vary by type of city.

\section{Community Differences in Problem Orientations in Poland and the United States}

When we scrutinize the data for these two sets of cities two observations strike us immediately: communities vary greatly and elites within communities, as well as among communities, vary greatly. Before proceeding with our analysis of the factors explaining elite perceptions of conflict, this multivaried community context or setting

Table 4. Perceptions of Problems by Local Elites in Poland and the US

\begin{tabular}{cccccc} 
Kalisz & Ostrow & Jarocin & Siedlce & Lukow & $\begin{array}{c}\text { Five } \\
\text { Polish } \\
\text { Cities }\end{array}$ \\
\hline $74 \%$ & $50 \%$ & $67 \%$ & $75 \%$ & 82 & $68 \%$ \\
20 & 45 & 18 & 20 & 14 & 25 \\
7 & 5 & 12 & 5 & 4 & 7
\end{tabular}

\begin{tabular}{|c|c|c|c|c|c|c|c|c|}
\hline \multirow{2}{*}{$\begin{array}{l}\% \text { of US leaders who see their } \\
\text { community as having "very } \\
\text { serious problems }\end{array}$} & \multicolumn{7}{|c|}{ US Cities } & \multirow{2}{*}{$\begin{array}{c}\text { Seven } \\
\text { US } \\
\text { Cities }\end{array}$} \\
\hline & Waukegan & Hamilton & South & Middletown & Wyandotte & Dothan & Park & \\
\hline 1. three or more problems & 57 & 47 & 41 & 24 & 23 & 16 & 0 & 29 \\
\hline 2. two problems & 7 & 13 & 12 & 35 & 23 & 5 & 7 & 16 \\
\hline $\begin{array}{l}\text { 3. one or two problems } \\
\text { (no problems at all) }\end{array}$ & $\begin{array}{c}36 \\
(29)\end{array}$ & $\begin{array}{l}40 \\
(7)\end{array}$ & $\begin{array}{l}47 \\
(18)\end{array}$ & $\begin{array}{c}41 \\
(12)\end{array}$ & $\begin{array}{r}54 \\
(8)\end{array}$ & $\begin{array}{c}79 \\
(58)\end{array}$ & $\begin{array}{c}93 \\
(64)\end{array}$ & $55^{*}$ \\
\hline
\end{tabular}

B. Type of Serious Problems** Mentioned:

\begin{tabular}{lcc} 
Mentioned: & Five Polish Cities & Seven US Cities \\
\cline { 2 - 3 } & $55 \%$ & $48 \%$ \\
& 86 & 8 \\
& 41 & 18 \\
41 & 14
\end{tabular}

Economic

Social

Service

Educational, Cultural, Recreational

\footnotetext{
* These respondents in the US study said there was only one or no "very serious" problem in their communities. There were no Polish respondents who said there was no serious problem.

** These are averages of the percentages of leaders in each city who mentioned a need or problems as "very serious" (US) or as "very much" unsatisfied (Poland).

Notes: Based on: US question - "Are any of the following issues a problem for your city - very serious, somewhat serious, no problem? (14 issues were listed plus "other").

Polish question - "What do you think are the most important problems facing your city now." (Over 30 problems were coded).

"To what extent, in your opinion, are the needs of the inhabitants of this town (village) satisfied in the following fields?" (20 specific types of needs were referred to). The alternatives used were: quite sufficiently, rather sufficiently, rather insufficiently.
} 
should be understood. To begin with we should note the differences in problem orientations by community, using our leaders as informants on this matter. In Table 4 we have arranged our cities on the basis of the perception that the community faces very serious problems. Over 50 percent of the leaders in Waukegan identify three or more serious problems confronting their city (47 percent in Hamilton), but in Wyandotte only 23 percent do, and in Highland Park 64 percent of the leaders see no serious problems at all. In Poland the variation is not that great, yet elite perceptions of the seriousness of problems varies also, ranging from 50 percent in Ostrow to 82 percent in Lukow (who see three or more very serious problems).

Second, the types of problems facing a city are somewhat different. Although almost 50 percent of US cities' leaders identify economic problems, the incidence of this type of problem is very high in Wyandotte (85 percent) and very low in Dothan and Highland Park, where leaders are more worried about social and service problems.

In Polish cities there is great variation in types of problems perceived. The proportion of leaders mentioning economic problems ranges from 37 percent in Kalisz to 73 percent in Lukow. Service problems are much less likely to be mentioned. Sixty percent mention housing problems in Kalisz but only 3 percent in Ostrow. Schools are also a problem in Lukow and Kalisz but not in Jarocin.

Third, the sense of "effective action" varies considerably (Table 5). At one extreme in the American data is Highland Park, 56 percent of whose elites have a sense of achievement in the solution of problems. Waukegan leaders seem the most frustrated, only 29 percent seeing effective action (on four or more problems). Other communities are split, a large minority of leaders feeling no action is occurring on serious problems.

Table 5. Community Variations in Effective Action on Problems

\begin{tabular}{|c|c|c|c|c|c|c|c|c|}
\hline \multirow{2}{*}{$\begin{array}{l}\% \text { of Polish leaders seeing } \\
\text { problems as "very much" } \\
\text { unsatisfied }\end{array}$} & & & \multicolumn{6}{|c|}{ Polish Cities } \\
\hline & & & Kalisz & Ostrow & Jarocin & Siedlce & Lukow & $\begin{array}{l}\text { rive } \\
\text { Cities }\end{array}$ \\
\hline \multicolumn{9}{|l|}{$\begin{array}{l}\text { four or more problems } \\
\text { not satisfied }\end{array}$} \\
\hline & & & 37 & 36 & 35 & 15 & 8 & 24 \\
\hline $\begin{array}{l}\text { three problems } \\
\text { two problems }\end{array}$ & & & 13 & 18 & 10 & 9 & 21 & 15 \\
\hline & & & 30 & 9 & 15 & 24 & 24 & 22 \\
\hline no problems & & & $\begin{array}{r}7 \\
13\end{array}$ & $\begin{array}{l}14 \\
23\end{array}$ & $\begin{array}{l}10 \\
30\end{array}$ & $\begin{array}{l}30 \\
21\end{array}$ & $\begin{array}{l}16 \\
32\end{array}$ & $\begin{array}{l}16 \\
24\end{array}$ \\
\hline \multirow{2}{*}{$\begin{array}{l}\% \text { of US leaders who } \\
\text { see serious problems } \\
\text { not dealt with at all }\end{array}$} & \multicolumn{8}{|c|}{ US Cities } \\
\hline & Wyandott & Midáletown & Hamilton & Waukegan & $\begin{array}{l}\text { Highland } \\
\text { Park }\end{array}$ & $\begin{array}{l}\text { South } \\
\text { Bend }\end{array}$ & Dothan & $\begin{array}{l}\text { Seven } \\
\text { Cities }\end{array}$ \\
\hline four or more problems & 8 & 6 & 0 & 0 & 0 & 0 & 0 & 2 \\
\hline three problems & 0 & 12 & 7 & 7 & 0 & 0 & 11 & 6 \\
\hline two problems & 8 & 0 & 36 & 21 & 7 & 6 & 11 & 12 \\
\hline one problem & 23 & 24 & 7 & 43 & 7 & 29 & $\tilde{\mathbf{j}}$ & 19 \\
\hline no problems & 61 & 58 & 50 & 29 & 86 & 65 & 73 & 61 \\
\hline
\end{tabular}


There is much more concern about lack of effective action among local elites in Poland. On the average over 50 percent see two or more serious problems not dealt with effectively (compared to 20 percent for the US local elites). But the variation in Poland is also considerable on this point-Kalisz's elite ( 37 percent) who says there are four or more serious problems not satisfactorily met, while the percentage in Ostrow is only 8 percent.

Communities vary also in the conflict perceptions of their elites. Certain US cities (such as Waukegan) obviously have a great deal of visible conflict, while others (such as Middletown) seem to have relatively little.

It is clear for the US cities that there are conflicts, that elites are aware of them, but that they place considerably different weights on these conflicts within the same community.

The Polish cities do not differ radically from the US cities in the conflict perceptions of their leaders. At least the proportions mentioning three or more conflicts as dividing the community are very similar. On the aggregate, 43 percent of Polish leaders said there were no serious conflicts; for the United States the proportion was 44 percent. And the comparisons of type of perceived conflicts are remarkably similar.

The evaluations of conflict which these local leaders have do not differ extremely in the aggregate (i.e., if we compare all Polish leaders with all American leaders). (See Table 6). We might have expected greater variance. Conflicts are seen on the average by 56 percent in the United States as interfering with effective action and by 23 percent as coming "very much" in the way of community development. The comparable Polish percentage for this latter perception is 31 percent. So far as personal normative views are concerned, American leaders are generally more proconflict than the Polish (on the six comparable items in our value scale), but not extremely so, 75 percent compared to 61 percent. The differences by community also do not seem extreme for either country; in fact, there appears to be considerable homogeneity in elite value orientations about conflict across these cities if one uses the overall index. If one inspects the data more carefully, however, one discerns considerable variation by community on particular value orientations. For example, for the statement "a leader should modify his actions to keep consensus," we find the range in agreement for our seven US cities to be from 20 percent to 60 percent and for our Polish cities to be 45 percent to 77 percent. The average range in proconflict responses for the six items was 21.0 percent for Polish cities and 30.5 percent for US cities, suggesting greater intercity variation in the United States.

This leads us to the question of elite consensus, or the integration of communities at the elite level (Table 7). There are different ways to operationalize elite consensus and dissensus, of course. One approach is to ask whether the elites agree on which (and how many) problems, if any, are the most serious. One sees, following this criterion, no great elite homogeneity in the US cities, with the possible exception of Highland Park. The elites in our samples are quite clearly split on the number of problems which are serious: $50-50,60-40$, or $80-20$. There is less disagreement on the type of major problems referred to. The great majority will agree that at least one key problem is "unemployment," or "economic development," or "social services," or the need for "public improvements." But there is disagreement over the number and type of other problems which are serious. On the question of effective action, again, one sees the same types of splits. That is, in Hamilton, for example, 50 percent of the leaders say effective action is negligible, and 50 percent say it is significant. 
Table 6. Community Variations in Elite Evaluations of Palitical Conflict: the US and Poland

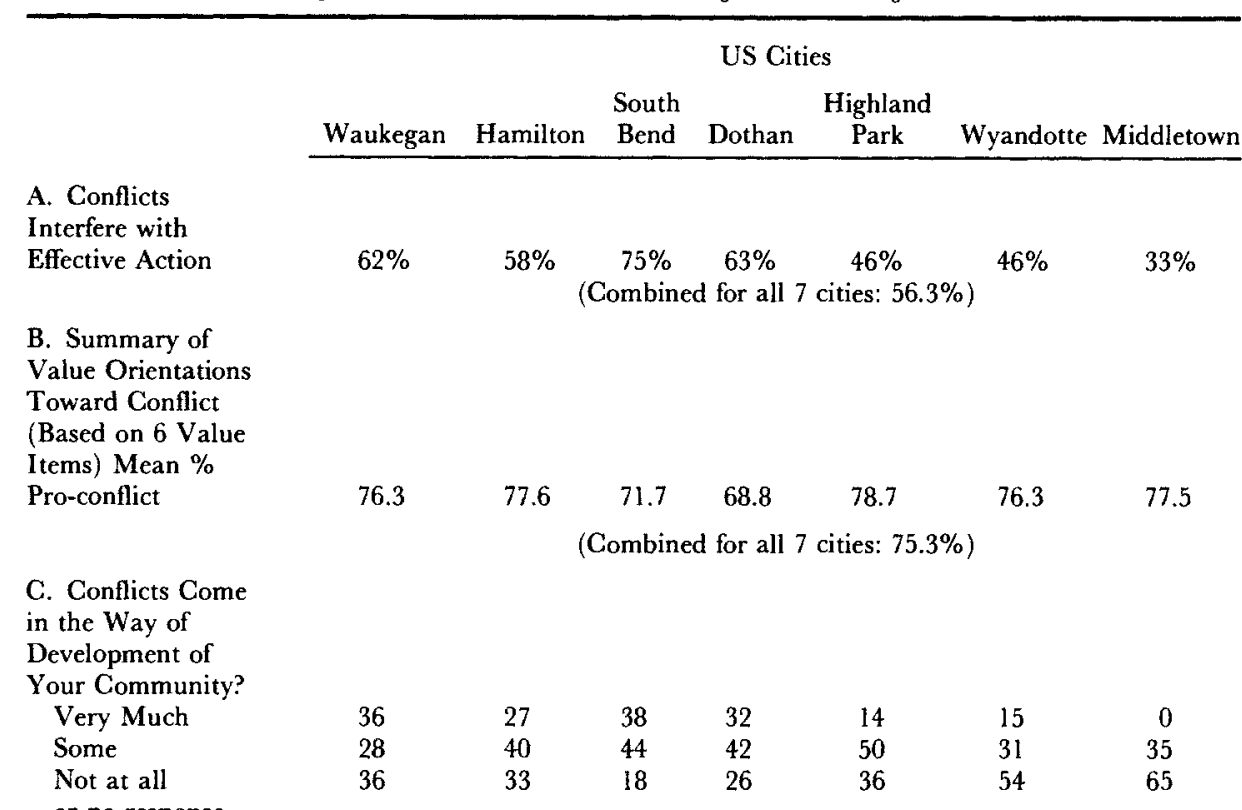

(For all 7 cities: Very much, $23.1 \%$; some, $38.9 \%$; not at all or NR, $38.0 \%$ )

\section{Polish Cities}

\begin{tabular}{llll} 
Kalisz Ostrow Jarocin & Siedlce Lukow \\
\hline
\end{tabular}

\begin{tabular}{|c|c|c|c|c|c|}
\hline \multicolumn{6}{|c|}{$\begin{array}{l}\text { A. Effect of Conflicts on } \\
\text { Community Development }\end{array}$} \\
\hline Harmful (obstruct) & $43 \%$ & $24 \%$ & $18 \%$ & $60 \%$ & $18 \%$ \\
\hline Helpful (promote) & 3 & - & 18 & 10 & 5 \\
\hline Conflicts irrelevant & 40 & 26 & 39 & 5 & 18 \\
\hline No response & 14 & 50 & 25 & 25 & 59 \\
\hline
\end{tabular}

B. Value Orientations Toward

Conflict (6 items as in US study)

Mean \% Pro-Conflict

64.5

$61.4 \quad 62.1$

$66.7 \quad 51.5$

(For all 5 cities: $61.2 \%$ )

Questions (US): "In many communities there are conflicts which interfere with effective action to meet community problems. Are there some major conflicts that interfere with getting things done in your community?"

"To what extent do these conflicts come in the way of the development of your community?"

Questions (Poland): "Do these conflicts in your opinion (1) obstruct the development of this area (2) promote the development of this area (3) have no influence on the development of this area?

In Middletown it is a 58-42 split. Only in Highland Park is this irrelevant, since such a large proportion of elites say there simply are no serious problems. Sizeable proportions present contrasting evaluations of the role conflicts play in the action process. Even in Highland Park, elites differ clearly in how they evaluate conflict.

The Polish data are strikingly different in that there is high elite agreement on the number of serious problems-on the average only 7 percent disagreement (compared to 35 percent for the US cities). But as to the question of effective action and whether conflicts interfere with development, the elite dissensus is not much different on the 
Table 7. Elite Consensus in US and Polish Cities

\begin{tabular}{|c|c|c|c|c|c|c|}
\hline \multirow[b]{3}{*}{$\begin{array}{l}\text { 1. Number of Serious } \\
\text { Problems Perceived - \% } \\
\text { disagreeing with the } \\
\text { majority (defined as those } \\
\text { who see } 2 \text { or more serious } \\
\text { problems) }\end{array}$} & \multicolumn{6}{|c|}{ Polish Cities } \\
\hline & Kalisz & Ostrow & Jarocin & Siedlce & Lukow & All five Cities \\
\hline & $7 \%$ & $5 \%$ & $12 \%$ & $5 \%$ & $5 \%$ & $7 \%$ \\
\hline $\begin{array}{l}\text { 2. Effective Action to } \\
\text { Satisfy Needs - \% who say } \\
\text { there is only one,or no, } \\
\text { need which is very much } \\
\text { unsatisfied }\end{array}$ & 20 & 48 & 51 & 40 & 37 & 40 \\
\hline $\begin{array}{l}\text { 3. Conflict Evaluation } \\
\text { - \% disagreeing as to } \\
\text { whether conflicts interfere } \\
\text { with development* }\end{array}$ & 43 & 24 & 18 & 15 & 18 & 24 \\
\hline
\end{tabular}

US Cities

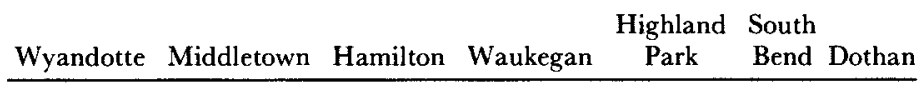

1. Number of Serious

Problems - \% disagreeing with majority (majority usually except for Wyandotte, Highland Park, and Dothan, see 2 or more very serious problems

$46 \%$

39

46
$41 \%$

$40 \%$ $36 \%$ $7 \%$ $47 \%$ $21 \%$

\section{Effective Action on} Problems - \% disagreeing with majority (in all cases except Waukegan the majority says serious problems are being handled)

3. Views as to Whether Conflicts Help or Harm Community Development - \% disagreeing with majority position (except for Wyandotte and Middletown the majority say conflicts interfere) 42 50 29 14

r

\footnotetext{
*Those who say conflict plays no role (harmful or helpful) are not included here.
} 
average than in the United States. The differences by cities, again, are considerable, almost as great in Poland as in the United States on effective action responses and greater in Poland than in the United States on whether conflicts are harmful. Thus one finds great elite diversity in problem and conflict perspectives by community in both systems.

Let us attempt a summary of the differences in these two systems for the two clusters of cities included in this analysis (see Table 8). These data suggest that the basic differences between the local elites in these two systems occur over their perceptions of the seriousness of community problems, the types of such problems, and whether effective action is being taken. In addition, US elites are somewhat more pro-conflict in value preferences. But the data on conflict perceptions are very similar, as is the level of elite consensus.

Polish cities face a variety of problems and conflicts. What seems clear is that a large number of local leaders are concerned with "unsatisfied needs," reflecting the

Table 8. Summary of Differences in the Two Systems

A. Problems and Action Perceptions

1. Perception of serious problems (on 3 or more community needs)

$\begin{array}{cc}\text { US } & \text { Poland } \\ (\mathrm{N}=108) & (\mathrm{N}=143)\end{array}$

2. Types of Serious Problems

Social

Economic

Educational-Cultural

Service

$29 \%$

$68 \%$

3. Dissatisfaction with Extent of Effective Action on Problems

3 or 4 needs not effectively dealt with

8

B. Conflict Perceptions

1. Amount of Conflict

Sees No Conflicts in Community

2. Types of Conflict Perceived

Income

Education

22

21

Political

16

17

Religious

8

86

55

41

41

18

valuation of Relationship of Conflict to

Community Development

Seen as Harmful

C. Personal Value Position on Conflict

Pro-Conflict Orientation

75

61

D. Elite Consensus or Dissensus

Disagree with the Majority

Position on Whether Effective

34 
very difficult economic and social situation of the early 1980s. Yet cities vary in their leaders' perceptions of problems and needs. Three factors appear to be particularly related to this variation: the role of a city in a province, the economic development status of a province, and the depth of the political crisis of the 1980s. Leaders in the provincial capitals (Kalisz and Siedlce) report a higher number of serious problems. This is not surprising, because of their greater dependence on centrally distributed goods (such as food, construction of apartment buildings) plus the different expectations in the larger urban communities (such as day-care centers, hospitals). While almost all leaders (over 90 percent) mention at least one economic problem, leaders in the provincial capitals are more concerned with social problems, especially to do with educational-cultural needs. Then, too, one must note that in the less developed province (" $S$ " province) the number of needs and serious problems perceived is higher. It is necessary to remember that need perception reflects not only the objective situation but also aspirations based on promises which may be unfulfilled. Thus in Kalisz the lack of a local university branch and an unfinished hospital (under construction for years) influenced local leaders' opinions.

A particularly relevant consideration in Poland may be leaders' perceptions of their autonomy in handling local problems. On 18 different types of problems the five cities range, in the percentage of their elites who feel that they do not have enough power to deal with the problem, from 80 percent who say they are constrained on hospital construction, 74 percent on construction of schools, 70 percent on housing construction, 64 percent on clothing supply, 55 percent on the supply of food, to 12 percent in the administration of municipal services and 15 percent in their control of cultural activities. On many of the most critical economic needs, therefore, leaders feel they cannot be effective, which is certainly reflected in their perceptions of the problems and need situation in their communities. There is some variation by community in these levels of perceived lack of power. Kalisz leaders apparently sense greater autonomy-only 41 percent feel lack of power in supplying food, 56 percent in supplying clothing-but in other areas of need the leaders of Kalisz, too, seem to lack authority to do much. Thus, 81 percent of the leaders are frustrated over the lack of autonomy to proceed with hospital and school construction and 78 percent report no power to move ahead locally with housing construction.

As for conflict perceptions, the local elites of the two largest cities of Kalisz province (Kalisz and Ostrow) see more conflicts than the leaders of the smaller cities and of the cities in Siedlce province. This can be explained by the particularly strong political conflicts in these two cities at the beginning of the $1980 \mathrm{~s}$, which contributed to leaders' awareness of many problems. Yet we note also the tendency of large numbers of Polish local leaders to deny the existence of conflicts. These results in our present study compare with the earlier results from the Polish study of 30 administrative districts in 1966, the study of six towns in 1977, and the 1978-80 study in these same provinces. The conclusion reached in 1982 was that:

The political consciousness of a large sector of local authorities is marked by a tendency to deny the existence of conflicts within the local community and to negate the importance of social differences. In 1978-80 some 28 to 30 percent of the leaders . . claimed that there were no conflicts . . . In 1966 only 15 percent of local leaders maintained that there were no conflicts... [suggesting] the tendency of the leaders not to perceive local conflicts increased from the mid-1960s to the mid-1970s (that tendency was reversed in the summer of 1980 in " $S$ " 
province) .... The data gathered by the Public Opinion Research Centre of Polish Radio and Television (OBOPISP) reveal that Polish society at large showed an increased tendency to perceive negative differences and conflicts in the mid-1970s as compared with the early 1960s.

This tendency to deny the existence of conflict and to make little of the importance of social differences which is typical of the leaders, can be explained by their acceptance of an ideology, connected with their group interest, which assumes the vanishing of class differences and conflicts in socialist society. (The ideological sources of this tendency can be inferred from the fact that it is more often observed in people working in the PUWP apparatus.) It seems, however, that it is also intensified by the conventional normative structures: orientation toward interpersonal harmony, law and order. It is obvious that the denial or even the belittling of conflict in a situation where it is commonly held that conflict is increasing cannot be considered rational. Given such a situation, rational action requires an institutional settling of conflicts, and this necessitates the admission that conflict is both real and unavoidable. (Jasinska and Siemienska, 1982).

Differences in income are still important sources of conflict in Poland, particularly visible in cities with higher levels of economic development. Differences in trade union membership (mainly "Solidarity") before December 13, 1981 (the imposition of martial law), and manual compared to non-manual workers are also perceived sources of conflict. It is necessary to point out that differences in political views were more often considered a source of conflict than party membership.

Conflict evaluation responses in Polish cities have changed somewhat over the years. Fewer local leaders see conflicts as harmful: in " $K$ " province 48 percent were anti-conflict in the 1970s, compared to 35 percent in the present study. The leaders in the large provincial capitals are more likely to be critical of conflict. Yet few leaders admit that conflict can be helpful, which is understandable if one recalls the position taken in party documents, which we mentioned earlier in the introduction. It is clear that most local leaders share the opinion that a condition of economic and social development is achieved by social integration and by mobilization around commonly accepted goals, that is goals formulated by the party whose leading role is constantly stressed.

\section{Individual Level Analysis}

While there can be no doubt that social and economic conditions as well as the conditions of political life in a community influence elite attitudes toward conflict, that is not the complete story. A major question is whether there are characteristics of leaders which predispose them to certain approaches to conflict despite the community, whether there are uniformities across communities which we can discover. Other studies referred to earlier suggest that this may be the case. We will use here four individual level characteristics on which we have data for both countries.

The first theoretical concern relates to leadership position or role. The national elite study found that administrators were more concerned, indeed negative, about conflict than MP's. The question is whether we find this to be the case at the city level. The answer is a qualified yes (see Table 9). In the United States, department heads had almost the same level of awareness of conflict as mayors and council 
Samuel J. Eldersveld and Renata Siemienska

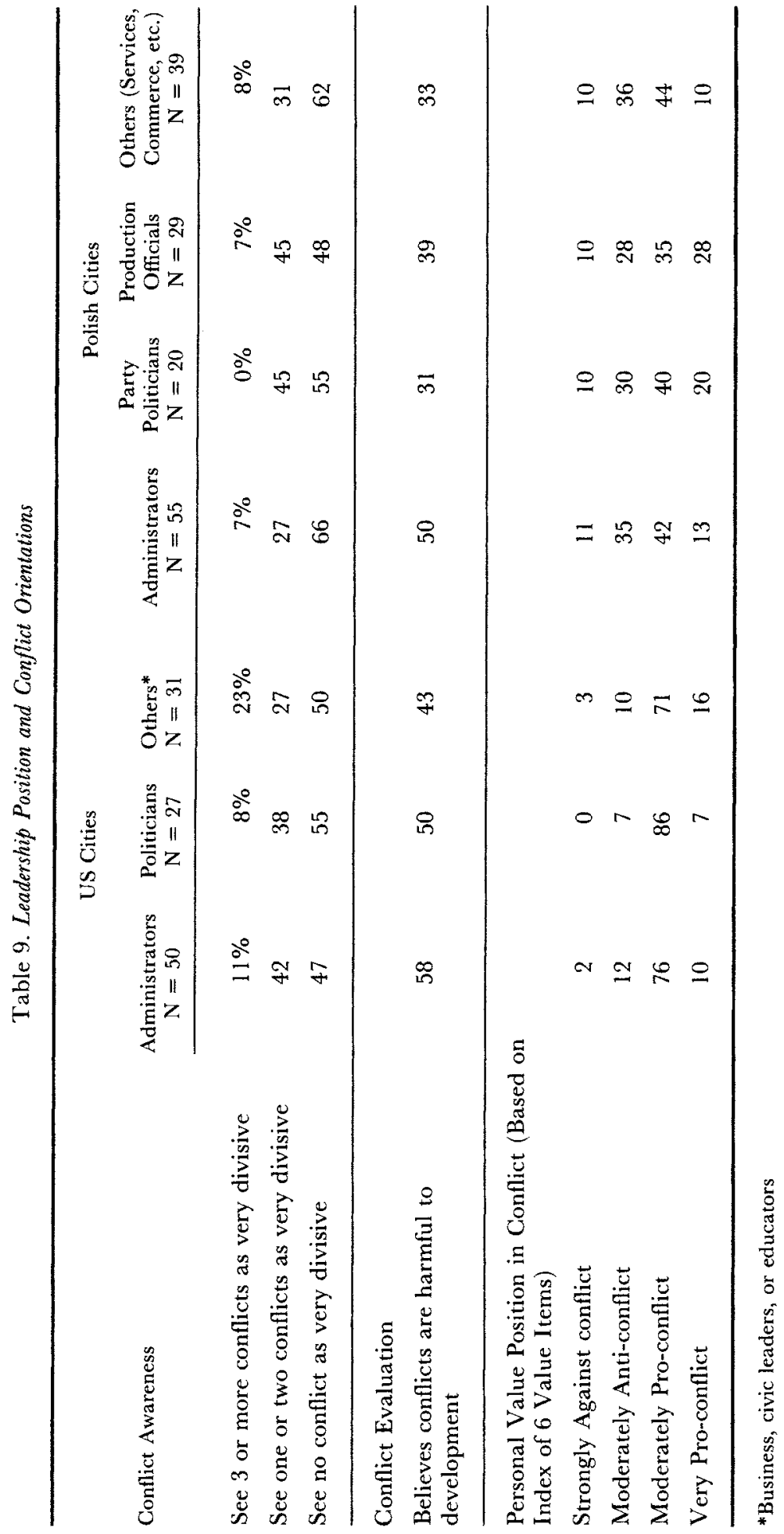


members, but they evaluated conflict somewhat more negatively. As for their personal value position, administrators were more inclined to argue for resolving conflicts as the top priority. But the differences are not great in the United States. In Poland, administrators actually see fewer conflicts than do the party politicians (although there is considerable homogeneity in the perceptions of all local leaders in this study). Polish administrators are more concerned about the harmfulness of conflicts (50 percent compared to 31 percent for the party politicians). What is surprising is that the latter, the members of the party apparatus, are so tolerant of conflict. The complete data for Poland reveal that 54 percent of the party people see conflicts as irrelevant to development (compared to 30 percent for administrators). It may be that these administrators are new members, only recently appointed to the local position. As to personal value positions, the Polish leaders of all types are much more anti-conflict than in the United States-Polish administrators 46 percent (US 14 percent); Polish party officials 40 percent (US 7 percent). This is a major cross-national difference, but our data do not indicate that the type of position a leader holds is a major explanatory variable in understanding his or her conflict orientations.

Party affiliation, a second factor, conceivably should play an important role in elite conflict orientations in both countries. The national elite studies in the West found conservative parliamentarians to be more pro-harmony, more concerned about conflict, than politicians on the "left." These local elite data do not support that finding at all, however. In the United States, Republican leaders see less conflict than either the Democrats or Independents, are less inclined to say it interferes with community progress, and personally espouse a value position which is significantly more pro-conflict. These American cities varied considerably in the partisan character of their elite samples at the time of our study-from 78 percent Democratic in South Bend, 57 percent Democratic in Waukegan, to a 43 percent Democratic and 21 percent Republican split in Highland Park, to 71 percent Republican in Middletown. Yet the Republicans seem consistently more tolerant of conflict.

In Poland one could argue either that party members should be less tolerant of conflict, and that therefore these findings are surprising, or that non-members would be expected to be more aware of conflict and more interested in seeing the need for social, if not political, consensus. More reflection as well as analysis of these data, probably in detail for each city, will be necessary to interpret these findings fully.

Length of tenure in leadership position seems to be only marginally related to elite conflict views. The Polish elites, paradoxically, are more inclined to see conflict as harmful if they have been in their positions most recently, for a short time (i.e. in the 1980-83 period), but they are somewhat more inclined to be personally tolerant of conflict than those who have been in position for a longer period. The American elites who have come into office only recently are somewhat less aware of conflict but more inclined to see it as harmful (as is the case for the Polish elites). Yet, tenure seems to be irrelevant to their own personal value position (which is somewhat contrary to the finding for Polish leaders).

Since the tenure variable is related to the age variable it makes sense here to compare these findings. Again, there are no very clear differences to be found. If one contrasts the youngest cadre and the oldest cadre one discovers one similarity crossnationally-the youngest elites are most likely to say there are no serious conflicts. Beyond that one finds only differences in the two systems: the youngest US elites are most inclined to see conflicts as harmful to the community (while in Poland the oldest 
elites do); the youngest US elites are somewhat more personally tolerant of conflict (while in Poland the oldest elites are more tolerant). The findings for the intermediate age groups reveal no linear set of relationships.

\section{Concluding Observations}

There are several surprising, if not troublesome, findings in this comparative analysis. We find, as expected, that the cities in both Poland and the United States are confronted by serious problems and conflicts and that there is genuine concern by elites as to whether effective action is being taken. What is surprising is the degree of cross-national uniformity in some of our findings. While it is true that the evidence of serious problems in Poland is reported at a higher level than in the United States, we find the types of problems reported to be similar. For example, there is evidence of serious economic problems, which are mentioned by 48 percent of the respondents in the United States and by 55 percent in Poland. As to the amount and types of serious conflict in their communities, both sets of elites, in the aggregate, are similar-roughly 55 percent see considerable conflict, and for certain categories of conflict the proportions are almost equal (conflicts over income status- 21 percent and 22 percent; conflict over political views -17 percent and 12 percent). Further, similar percentages of those leaders see conflicts as harmful to community development: 23 percent in the US sample, 31 percent in the Polish sample. Elite dissensus by community in each country is similar also, between 30 percent and 40 percent. In our individual level analysis we found some cross-national uniformities also. Thus bureaucrats see conflict as more harmful than politicians; as for personal value orientations, the politicians are more conflict-tolerant in both systems.

One would have expected more evidence of system-specific differences in these "most different systems." There are indeed certain unique findings for each country. The youngest cadre in Poland is relatively much more pro-conflict than the older elites, while the reverse is true in the United States. The party members in Poland are much more pro-conflict than one would have expected given the party's ideological dogma on conflict. Republicans in the United States are more tolerant of conflict than the Democrats, and less concerned about the harmful consequences of conflict. But these are specific findings which do not overcome one's surprise at the basic pattern of cross-national uniformities in the findings. One might have expected that in Poland the greater drive for consensus and harmony by the system would be

Table 10. Comparison over Time of Value Orientations of Elites

\begin{tabular}{ccc}
\hline & $\begin{array}{c}\text { ISVIP } \\
1966\end{array}$ & $\begin{array}{c}\text { Our Study } \\
1980-84\end{array}$ \\
\cline { 2 - 2 } & & \\
$\begin{array}{l}\text { Personal Value Orientation } \\
\text { of Local Elites } \\
\text { \& Pro-Conflict } \\
\text { Poland }\end{array}$ & & \\
US & $53 \%$ & $61 \%$ \\
\hline
\end{tabular}


manifest in a set of elite responses on conflict perceptions, conflict evaluations, and personal conflict value orientations-particularly by the established party elite. Rather, we find the local Polish elites converging more toward the American model of local politics: much perceived conflict, relative ambivalence as to its harmfulness, great tolerance of conflict in terms of personal value position.

The comparison with the 1966 ISVIP data is interesting in this respect (see Table 10). Although one must be cautious with these data and remember the smaller number of cities included in the 1980-84 study, the "convergence" trend is suggestive.

In one final respect the two systems are similar-there are great variations by local communities in types of problems, types of conflicts, and in elite orientations to these problems and conflicts, in their communities. It is these within-system variations, as within-elite dissensus, that best characterize local political elite cultures in these two systems. As Lasswell said long ago, "Elite studies are the heart of research into the world revolution of our time!"

\section{Note}

1. This study, known as ISVIP (International Study of Values in Politics, Jacob, 1971) will be referred to here as the "Values Project."

\section{References}

Aberbach, J., et al. (1981). Bureaucrats and Politicians in Western Democracies. Cambridge, MA.: Harvard University Press.

Coleman, J. (1957). Community Conflict. New York: The Free Press.

Coser, L. (1956). The Function of Social Conflict. New York: The Free Press.

Dahl, R. (1967). Pluralist Democracy in the U.S.: Conflict and Consent. Chicago: Rand-McNally.

Dahrendorf, R. (1959). Class and Class Conflict in Industrial Society. Stanford, CA.: Stanford University Press.

Dahrendorf, R. (1969). Society and Democracy in Germany. Garden City, NY: Doubleday.

Eldersveld, S. J. (1981). Elite Images of Dutch Politics. Ann Arbor, MI: University of Michigan Press.

Gamson, W. A. (1968). Power and Discontent. Homewood, IL: The Dorsey Press.

Jacob, P., et al. (1971). Values and the Active Community. New York: The Free Press.

Janowitz, M. (1970). Political Conflict. Chicago: Quadrangle Books.

Jasinska, A. and R. Siemienska (1982). "Local Authorities Prior to the Crisis of 1980." Sisyphus, III.

Lasswell, H. (1930). Psychopathology and Politics. Chicago: University of Chicago Press.

Lipset, S. M. (1960). Political Man. Garden City, NY: Doubleday.

McNeil, E. B., ed. (1965). The Nature of Human Conflict. New York: Prentice Hall.

Putnam, R. (1973). The Beliefs of Politicians. New Haven, CT.: Yale University Press.

Siemienska, R. (1984). "Popular Demands and Leadership Responses in Periods of Economic Retreat: A Case Study of Poland." Presented at the International Conference on Comparative Studies on Values and Fulfillment of Needs by Local Governments in Jablonna (Poland).

Simmel, G. (1904). "The Sociology of Conflict." American Journal of Sociology. IX.

Sperlich, P. (1971). Conflict and Harmony in Human Affairs. Chicago: Rand-McNally.

Sprawozdanie $\mathrm{z}$ prac komisji KC PZPR powołanej dla wyjaśnienia przyczyn i przebiegu konfliktów społecznych w dziejach Polski Ludonej (Report of the Special Commission of the 
the Central Committee of the Polish United Workers' Party). (1983). Nowe Drogi, Special Issue.

Szczepanski, J. (1984). "Poland 1984: Reflections upon Forty Years of Development." In Eastern Europe in the Aftermath of Solidarity (Adam Bromke, ed.) New York: Columbia University Press.

UNESCO Report (1957). The Nature of Conflict.

\section{Biographical Notes}

SAMUEL EldERSVELD has taught at the University of Michigan for over forty years, publishing in the fields of political party systems, comparative political behavior, and political elites, national and local. He is currently doing a comparative study of local political elites in the United States, Sweden, and The Netherlands. ADDREss: Department of Political Science, University of Michigan, 560l Haven Hall, Ann Arbor, MI. 48104, USA.

RENATA SIEMIENSKa teaches at the Institute of Sociology at the University of Warsaw. She has lectured widely in Poland, Europe, and the United States. Her research has focused on many different political and social problems in Poland, including cultural and social change, women and politics, gender sociology, comparative socialization, and local government. She recently co-authored a book on Poland, entitled Local Authorities at the Time of the Crisis (1987). ADDREss: Institute of Sociology and Philosophy, University of Warsaw, 00330 Palace Staszica, Warsaw, Poland. 